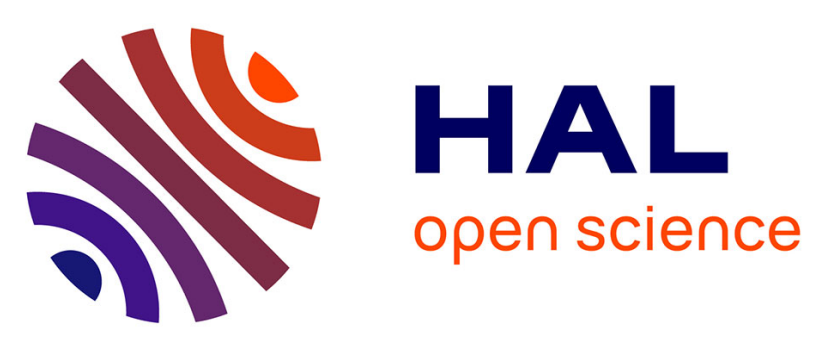

\title{
Satellite images combined with field data reveal negative changes in the distribution of babassu palms after clearing off amazonian forests
}

Danielle Mitja, Eric Delaître, Alessio Moreira dos Santos, Izildinha de Souza Miranda, Roberta Fatima Rodriguez Coelho, Deiane Jorge Macedo, Laurent Demagistri, Michel Petit

\section{To cite this version:}

Danielle Mitja, Eric Delaître, Alessio Moreira dos Santos, Izildinha de Souza Miranda, Roberta Fatima Rodriguez Coelho, et al.. Satellite images combined with field data reveal negative changes in the distribution of babassu palms after clearing off amazonian forests. Environmental Management, 2018, 61 (2), pp.321 - 336. 10.1007/s00267-017-0965-6 . ird-01715182

\author{
HAL Id: ird-01715182 \\ https://hal.ird.fr/ird-01715182
}

Submitted on 22 Feb 2018

HAL is a multi-disciplinary open access archive for the deposit and dissemination of scientific research documents, whether they are published or not. The documents may come from teaching and research institutions in France or abroad, or from public or private research centers.
L'archive ouverte pluridisciplinaire HAL, est destinée au dépôt et à la diffusion de documents scientifiques de niveau recherche, publiés ou non, émanant des établissements d'enseignement et de recherche français ou étrangers, des laboratoires publics ou privés. 
Satellite images combined with field data reveal negative changes in the distribution of babassu palms after clearing off Amazonian forests

Mitja D. ${ }^{1}$, Delaître E.1, Santos A. M. ${ }^{1,2,3}$, Miranda I. ${ }^{2}$, Coelho R.F.R. ${ }^{4}$, Macedo D. J. ${ }^{1}$, Demagistri L. ${ }^{1}$, Petit M. $^{5}$

1. UMR 228 ESPACE DEV (IRD-Institut de Recherche pour le Développement, UM -Université de Montpellier, UG-Université de Guyane, UR-Université de La Réunion, UA-Université des Antilles), MTD-IRD, 500 Rue Jean François Breton, 34093 Montpellier, cedex 5, France.

2. ISARH-Instituto Ambiental e de Recursos Hídricos, UFRA-Universidade Federal Rural da Amazônia, CP.917, 66077-530 Belém, Pará, Brésil.

3. IEDAR-Instituto de Estudos em Desenvolvimento Agrário e Regional (UNIFESSPA-Universidade Federal do Sul e Sudeste do Pará), Folha 31 Quadra 07 Lote Especial, Nova Marabá. 68507-590 Marabá,Pará Brésil.

4. IFPA-Instituto Federal de Educação, Ciência e Tecnologia do Pará- Campus Castanhal, Br-316 km 62 s/n. Bairro Saudades II Cristo Redentor,, 68740-970 Castanhal, Pará, Brésil.

5. IRD, 911 avenue agropolis, 34394 Montpellier, France

Corresponding author

Danielle Mitja, danielle.mitja@ird.fr, 0033467558636

\section{Acknowledgements}

This project has benefited from the support of the fondation Agropolis Open Science program (project: Gestion durable du Babaçu, 2014-2017, support agreement 1202-072), of the CNES TOSCA program (project: CIC-TOOB 2013-2014, research convention 130318), of the IRD - PPR Amazon program (project : ECOTEL 2013), of the CNPQ/UFRJ/IRD project : Relais (2012-2015), of the IRD (Institut de Recherche pour le Developpement), of the CNPq (Conselho Nacional de Desenvolvimento Científico e Tecnológico), from the UFRA (Universidade Federal Rural da Amazônia).

The authors thank the students who participated in the data collection between 2001 and 2008 and in particular Márcia Nazaré Rodrigues Barros, Marcos Antônio Leite da Silva, Roberta de Fátima Rodrigues Coelho and Alessio Moreira dos Santos. We thank Dr. Morgan Mangeas (IRD, UMA ESPACE-DEV) for statistical help. 
The authors thank the farmers of the PA-Benfica community for their help, availability and conviviality during the accomplishment of this work, and Mr. Deurival da Costa Carvalho for his efficiency and enthusiasm during on-site work.

\begin{abstract}
When the Amazonian rain forest is cut to create pasture, some of the original vegetal species survive clearing, even express their ability to invade agro-systems. It is true of the babassu palm which can be considered, paradoxically, as natural ressource by the "Interstate Movement of Babassu Fruit Breaker Women" or native weed by land owners-farmers. To manage potential conflict of land uses, we study here the current density of this palm tree in different habitats, based on a combination of field data and remote sensing data. Firstly, we checked that the field survey methodology (i.e. counting free-trunk palm trees over $20 \mathrm{~cm}$ in circumference) provides density values compatible with those stemming from satellite images interpretation. We can see then that, a PA-Benfica Brazilian territory revealed an average density of the babassu lower in pastures (2.86 ind/ha) than in the dense forest (4.72 ind/ha) from which they originate and than in fallow land (4.31 ind/ha). We analyze in detail density data repartition in three habitats and we discuss results from the literature on the density of this palm tree versus its resilience at different developmental stages after forest clearing, depending on anthropogenic - or not - factors, including solar radiation, fire, weeding, clear cutting, burying fruit, and competition with forage grass. All these results can be exploited for the design of future management plans for the babassu palm and we think that the linked methodology and interdisciplinary approach can be extended to others palms and trees species in similar problematic issues.
\end{abstract}

\title{
Key words:
}

Resilience, VHSR satellite images, family farming, field data, photo-interpretation, LCC-large circular crown palm tree 


\section{Introduction}

Managing tropical forests involves preserving biodiversity, a worldwide concern that has been explicitly addressed by international efforts such as the Convention on Biological Diversity in 1992 and 2002, and the Millennium Ecosystem Assessment in 2005. In the Amazon rainforest of Brazil, the main cause of deforestation is the creation of pastures through slash-and-burn agricultural techniques (Faminow 1997; Fearnside 2001). This process drastically changes species richness and plant community composition (Fujisaka et al. 1998, 2000; Mitja et al. 2008; Mitja and Miranda 2010). Indeed, agricultural intensification and its associated land use shifts are cited as the main cause of biodiversity loss (Sala et al. 2000; Wood et al. 2005; Leadley et al. 2010). In the Amazon, in areas of active deforestation (i.e., "pioneer fronts"), mechanical clearing is often followed by intensive farming; as a result, the primary forest is almost entirely eliminated and the land is colonized by secondary successional species. In contrast, when clearing is manual and carried out by smallholders, certain forest natives species persist in newly created pastures, due in part to the species' natural resistance to fire and open habitat conditions and in part to farmers allowing certain trees and palms to remain in their agroecosystems (Mitja et al. 2008; Santos and Mitja 2011). In the pastures used by farmers of the PA-Benfica settlement project $^{1}$, where this study was carried out, the babassu palm Attalea speciosa Mart. ex Spreng., forest species, is the most common and abundant palm tree species.

In the forests of Brazil, the babassu palm grows to heights of $30 \mathrm{~m}$. In nature, it occurs in the Amazon rainforest, in the Cerrado (Brazilian tropical savanna), at the interface between the Amazon rainforest and the Caatinga (xeric shrubland and thorn forest), and in the Atlantic forest. It covers a vast amount of land, an estimated 200,000 km² (May et al. 1985). The species has been observed in 13 Brazilian states (Anderson et al. 1991; Henderson et al. 1995; Shiraishi-Neto 1999; Rufino et al. 2008; Araújo and Lopes 2012). In Brazil, the babassu palm is frequently exploited. The Interstate Movement of Babassu Fruit Breaker Women (Movimento Interestadual das Quebradeiras de Coco Babaçu - MIQCB) has compiled a list of around sixty different uses, many of which involve the oil extracted from its seeds.

It is a species of potential economic value which may present benefits for the populations using it, even though it tends to act as an invasive in agroecosystems. The Brazilian Institute for Geography and Statistics (Instituto Brasileiro de Geografia e estatística - IBGE) gathers figures on the harvesting and commercial sale of the babassu's seeds.

\footnotetext{
${ }^{1}$ PA-Benfica is a settlement project implemented by the Brazilian Institute for Agrarian Reform (INCRA) that helps family farmers get established.
} 
When it comes to the exploitation of the babassu palm, societal and economic issues are tightly linked. The species is a source of conflict among different groups in the Brazilian society. For large landowners in rural areas and city dwellers, the babassu is an invasive species to be destroyed or a plant of little interest, even as ornamental garden plant. This perspective contrasts sharply with that of migrant populations present on "pioneer fronts," areas where the rainforest is actively being cleared. These populations are most often composed of family farmers who are getting established or families without lands. In particular, the women harvest the fruit of babassu to extract its seeds to provide an often crucial contribution to livelihood of their families. These newly established farmers must just keep babassu expansion under control to avoid competition with forage or foodproducing crops.

Given the availability of satellite images with very high levels of spatial and spectral resolution, it is now possible to assess the presence of certain tree or palm species in deforested tracts of land. A series of remote sensing studies examining vegetation have already been published. Some found that secondary forest composed of babassu palms can be discerned using Landsat TM images, which have a resolution of $30 \mathrm{~m}$ (Thales 1999). Others discovered that SPOT 5 images with a spatial resolution of $2.5 \mathrm{~m}$ cannot be used to detect individual palm trees within pastures (Silva 2008). Up until a few years ago, identifying and delineating the crowns of trees was a task accomplished using aerial photographs (Koch 2002; Jing et al. 2012), because of their higher level of spatial resolution. Using very high spatial resolution (VHSR) satellite images $(<1 \mathrm{~m})$, it is possible to identify the crowns of trees present in agroecosystems (Mougel et al. 2007; Mougel and Lelong 2008), urban zones (Ardila et al. 2012b) and open forests (Aourach 2013). Advances in remote sensing have made it possible to automatically detect tree crowns (Culvenor 2002; Ardila et al. 2012a; Ke and Quackenbush 2011) and methods for detecting particular species are being developed (Shafri et al. 2011). However, these researches focus on single-species formations such as tree plantations line or secondary forests. Research in high species diversity situations is more complex. The ability to identify species on VHSR satellite images, even by photo interpretation, requires extensive familiarity with such species in the field.

The results of generally accepted field studies conducted at plot level suggest that the density of adult babassu palms is higher in anthropic environments than in the original forest in which it originated (Barot et al. 2005; Anderson and May 1985; Peters et al. 1989). These authors thus emphasize the persistence of babassu in agro-ecosystems. However, the validity of these data has never been confirmed at the level of the landscape. The aim of our study was thus to test this hypothesis using field data on a site located in the Benfica region where we 
previously conducted vegetation quadrat sampling as part of a 2001-2008 biodiversity study. We used photo interpretation to analyze VHSR satellite images acquired by a GeoEye satellite on July 2009. The field data and satellite image data were used to examine the occurrence and density of the babassu palm across different types of habitat (pasture, primary forest, and fallow land), in an area corresponding to a project to install family farmers on the Amazon frontier: PA-Benfica. We explain the densities obtained in each type of land cover through anthropogenic factors and the resilience of the species. We also determine if and how pre-existing biodiversity datasets, previously obtained by field sampling following a different initial goal, can be used to validate results obtained from satellite data.

\section{Materials and methods}

\section{Study area}

The study was carried out in the Benfica community (S05 $\left.16^{\prime} 08.4^{\prime \prime} \mathrm{W} 49^{\circ} 50^{\prime 2} 29.1^{\prime \prime}\right)$ in Itupiranga village, near the city of Marabá, in the south of Pará state, Brazil. Climate is humid tropical, with a 7-months rainy season, between October and April, and a 5-month dry season (Reynal et al. 1995). The average annual rainfall is $2015 \mathrm{~mm}$, potential evapotranspiration is $1395 \mathrm{~mm}$, average annual temperature is $26.8^{\circ} \mathrm{C}$ and relative humidity varies between 76.9 and $88.4 \%$. Vegetation is a "terra firma" tropical rain forest (RADAMBRASIL 1974), characterized by the presence of creepers and palm trees. The study area is located in the "castanhais polygon" well-known for its outstanding concentration of Bertholletia excelsa H.B.K. that produces much valued Brazil nuts. The landscape is comprised of hillocks with horizontal extensions varying from 200 to 1000 $\mathrm{m}$, developed on granulites and granites, connected at the Itacaiunas formation of the Brazilian shield (PaleoProterozoic). Clayey ferralsols (ISSS Working Group 1998) are the dominant soils. However, from the top of the hillocks to the low-lying areas, depth of the permeable horizon decreases from $>3 \mathrm{~m}$ to $<1 \mathrm{~m}$. At the top of the slope, where vegetation surveys have been made, soil is deep, allowing vertical water drainage on slopes varying from 5 to $15 \%$ (Mathieu et al. 2004; Grimaldi, unpublished data).

The Benfica area was mostly covered with rain forest at the time of the farmers settling, in 1989. Forest is usually cleared for farmland in the dry season (May to July). A few palms including babassu, and valuable timber species are retained. Other trees and undergrowth are cut and left for at least one month to dry before burning (August to September). At the onset of the rainy season around November/December, farmers plant 
upland rice in the recently burnt fields, after removing all weeds. Pasture grass is planted jointly or within 30-60 days, with the aid of a manual dibble. The farmer often carries out a weeding in February/March, and all weeds are removed. In May rice is harvested and weeding allows forage grass (Brachiaria brizantha or Panicum maximum) to grow fast in the absence of any competitor. Cattle are allowed to graze after the first forage grass seed production, from June onwards, and the pasture is burnt in August/September after drying out during the dry season. Thereafter, fires occur at variable frequencies, depending on deliberate setting or spreading from neighbouring land. Manual weeding is done once or twice a year, generally in September/October before fire and then in April/May. Grazing patterns vary according to the farmer's technical choices, financial possibilities and availability of other pastures. Sometimes, rice fields may not be sown or recently sown pastures not weeded, leading to immediate abandonment to fallows. Therefore, fallows occur after different farming histories, from a single rice crop to many years of continuous grazing.

\section{Biological and social keys to the distribution of babassu on the PA-Benfica}

Prior to the 1970s, rainforest covered almost all the lands now occupied by PA-Benfica farmers. The babassu is a rainforest native species. In the rainforest, the palm's fruit fall down the litter near the feet of the adult plants. Underneath the canopy, there is little light and the microclimate is very humid, even during the dry season. Seedlings are abundant, (Khan and De Granville 1992; Barot et al. 2005), especially just beneath adults. Like many other rainforest species, young babassu palms grow slowly (Mitja and Ferraz 2001) and require access to light gaps to develop properly. Young caulescent and adult babassu also demonstrate slow growth (Anderson 1983). In the rainforest, palms reach reproductive maturity at around 108 years old (Anderson et al. 1991). The babassu adults are also present in pastures and crops after the clearing of primary forest. The babassu produces large, indehiscent fruit ( $200 \mathrm{~g})$ that fall to the ground at the foot of the parent palm tree; they can remain at the surface or become partially buried. Sometimes, fruit are dispersed. Barochory, hydrochory and zoochory have been observed (Smith 2015). Humans may also contribute to dispersal, especially within agroecosystems and over very short distances. Germination is cryptocotylar since the seeds remain enclosed in the fruit (Anderson 1983), allowing the embryo to reach a soil depth of $25-30 \mathrm{~cm}$. The babassu palm has a life cycle with six growth stages. In stage 1, the seedling is produced following seed germination. In stages 2 to 4 , the young plant is acaulescent and forms rosettes. In stage 5, the plant becomes caulescent and, in stage 6, it reaches reproductive maturity and displays unisexual male and female flowers. 
The babassu fruit is collected after it has fallen to the ground. Since the infructescences on a given tree mature at different times, it is common for certain fruits to remain unharvested. Furthermore, some fruits will be rapidly dispersed by wild fauna. They are these fruits that help ensure species regeneration. Women harvest the fruits; sometimes, they are accompanied by their children or husbands. Although they collect fruits in all three types of habitat, they prefer to do so in pasture. Various reasons are given - for instance, transporting the fruits is easier in open environments, the palms in pastures produce more fruits, and pastures are situated nearer to inhabited zones. On the PA-Benfica lands, just three women collect babassu fruits to extract oil, which they subsequently sell (Macedo 2015). They harvest fruits from just 4\% of the total land surface area. Other women in the local community occasionally collect fruits for personal use. As a result, fruits harvesting has a limited, localized impact on babassu palms occurring on PA-Benfica lands indeed, most fruits are left on the ground, and this activity only minimally affects babassu density.

\section{Quadrat sampling in the field}

From 2001-2008, we carried out quadrat sampling in the field on PA-Benfica lands. The intial goal was to characterize local plant diversity in different habitat types. We thought those data could be used again and adapted to the present study. We present just below how and in which context they were acquired.

We surveyed 62 pastures of PA-Benfica, covering a total of 487 ha. We noted the occurrence and density of adult trees and palms, which were identified to species using their taxonomic traits. We wished to determine which species would best serve in the integrated afforestation of pastures in the Amazon (Santos 2007; Santos and Mitja 2011). Only trees or palm trees of more than $20 \mathrm{~cm}$ in trunk or stipe circumference (i.e., $6.37 \mathrm{~cm}$ in diameter) were taken into account in that previous study. Moreover, only palm trees withaboveground free stem were recorded.

Plant richness in tracts of primary forest was characterized using 17 quadrats that covered a total of 0.85 ha, and plant richness on fallow land was quantified using 27 quadrats covering 1.35 ha (Silva 2004; Coelho 2008; Barros 2007). The numbers of individuals of different species were counted (in primary forest and fallow quadrats). Samples were taken, and plants were identified using the herbarium at the Emilio Goeldi Museum in Belém; a list of the species present was thus generated. In these analyses, we only retained individuals occurring in the upper layer with a diameter at breast height $(\mathrm{DBH})$ greater than $10 \mathrm{~cm}$. Those included younger palms with leaves at the base of their stems and adults with above-ground free stems. 
For the present study, out of these previous data, we only examined the ones for the palm family (Arecaceae). Firstly, we have to consider that trunk diameters or circumferences of individuals were not recorded during the field campaigns; we can only access a class value: whether DBH is greater or smaller than $10 \mathrm{~cm}$ in forests and fallow lands, and whether trunk circumference is smaller or greater than $20 \mathrm{~cm}$ in pastures. Secondly, data about younger palm trees was not recorded for pastures as it was for forests and fallow lands. So, in this study, we cannot extract the density of the palms for the forest and the fallow land, with the same rules as for the pastures.

Palm trees present on the PA-Benfica were characterized by data from the literature and our own measurements. We used such traits as leaf size and shape, crown shape, stem height and circumference, and the presence of a single or multiple stems. We have separated palm trees whose diameter of the crown was greater than $6 \mathrm{~m}$ assigning them a specific category, named: "palm trees with large circular crown" or LCC palm trees. Babassu palm tree belongs to such a group.

\section{The contribution of remote sensing}

We identified LCC palm species found on PA-Benfica lands via photo-interpretation.

We used a satellite image from the GeoEye sensor. The spatial resolution of this satellite image described as very high resolution is $0.41 \mathrm{~m}$, resampled to $0.50 \mathrm{~m}$ in panchromatic. It was taken in July 2009 . Two types of data were extracted from the image by photo-interpretation. On the one hand the individual labeling of each observed large circular crown palm (LCC), and on the other hand, the land use of transects (see below)

Individual tracking of LCC palms, whose babassu is part of, is possible with the naked eye on the GeoEye satellite imagery. However, it was not possible to differentiate the babassu palm from other LCC palms. A grid of 1-ha cells was superimposed on the satellite image. A transect method was then used to quantify palm occurrence and density on PA-Benfica lands: vertical transects $100 \mathrm{~m}$ wide were examined every km. Two additional zones were sampled-one to the southeast of PA-Benfica lands and the other to the southwest. Overall, LCC palm occurrence and density were determined for 2,354 cells (Fig. 1). We were only able to count palms whose stems were above ground. When a stem is still buried, it is hard to detect because the tree's leaf sheaths and petioles are almost entirely vertical. In contrast, once the stem has emerged, as is the case for older plants, palms tend to progressively adopt a more horizontal position. Seen from above, as on satellite images, 
palms resemble wheels, with regularly spaced spokes radiating out from a center point. The shadows of the stem and the crown can also be seen on the surface of pastures.

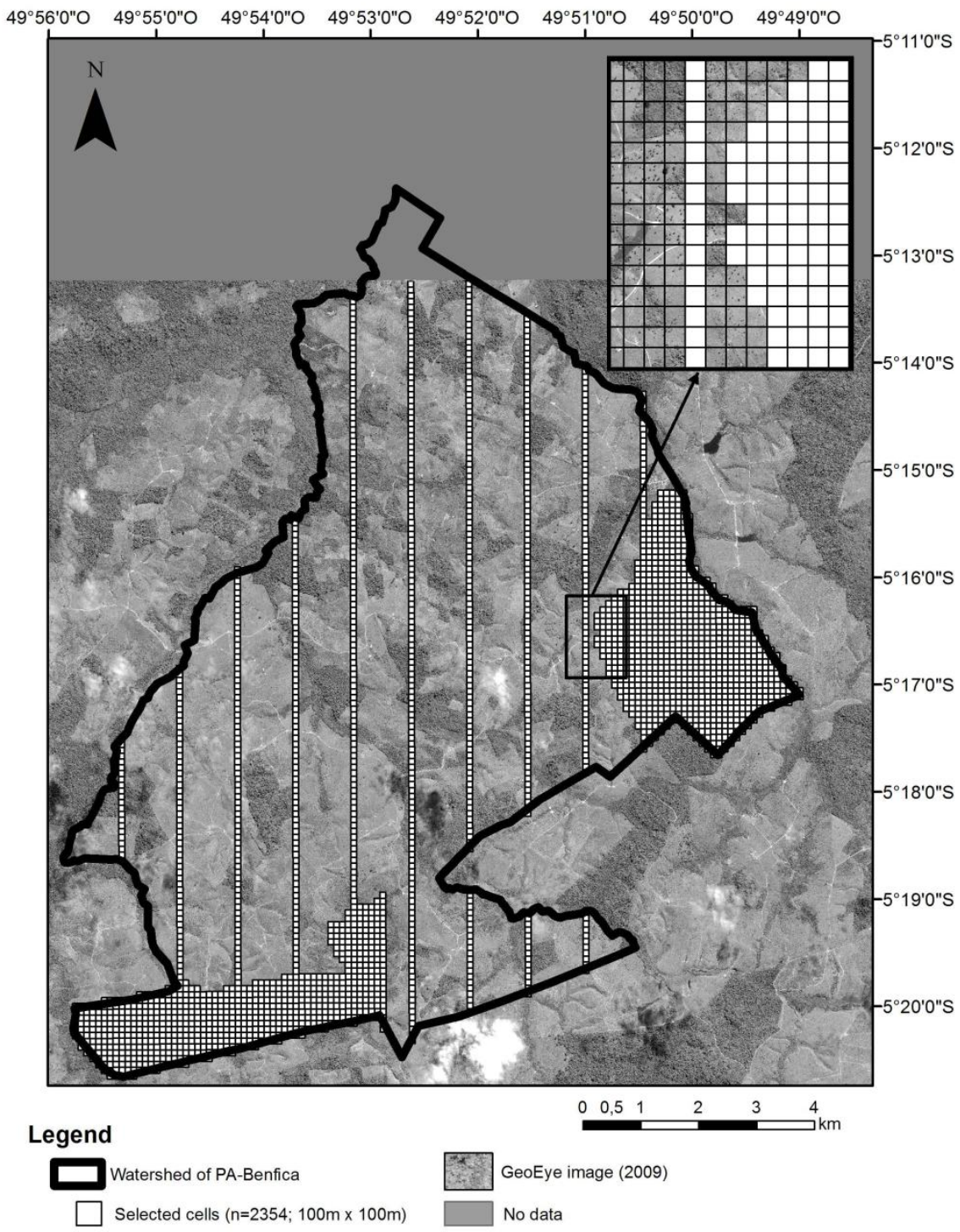

Fig. 1 Location of the 2,354 1ha-cells sampled on the PA-Benfica

We also determined the habitat type of each of the 2,354 cells surveyed. Four categories were defined: primary forest, fallow land, pasture, and mixed use. Primary forest is forest that has never been cleared in recorded history. However, it is important to note that timber has often been taken from such forests. Fallow land actually comprises a range of landscapes - from recently abandoned pastures invaded by woody plants to several-decade-old secondary forests. Such land can be used again in the future depending on changes in family composition or in the concentration of land ownership. The pastures vary in age and in the degree of invasion by herbaceous or woody opportunistic species. The mixed-use category contains tracts of land that are being used in two to three different ways, with a variable percentage of surface area dedicated to each use. 


\section{Statistical analyses}

For both the field data and the satellite-image data, the mean number of individuals per hectare was calculated for primary forest, fallow land, and pasture. Transects with mixed-use land were not considered. Because the field methodology used for primary forest and fallow land was the same, we compared mean palm densities for the two habitat types using a Mann-Whitney-Wilcoxon test, alpha level of 0.05 was used; this nonparametric approach was more appropriate given our small sample sizes and the non-normal distribution of the data. Because a different methodology was used in pastures (i.e., individuals with smaller diameters were included), we did not compare the mean palm densities between pastures and the other two habitats.

Concerning satellite data, a statistical method GLM (generalized linear model) was used to explain mean palm densities (dependent quantitative variable) by the land use (explanatory qualitative variable with three modalities: primary forest, fallow land, and pasture). As the dependent variable is a count variable, a GLM analysis was carried out with the argument "Poisson" as family distribution. Then the Bonferroni test was used to conduct pair-wise comparisons between palm densities means observed in each land use types.

All our statistical analyses were carried out using R (R Development Core Team 2011).

\section{Results}

\section{Shapes and sizes of palm trees}

Quadrat sampling revealed that 12 palm species are present on PA-Benfica lands (Table 1a and b). Only one, Oenocarpus distichus Mart, has a rectangular crown. Three are clumping palms (i.e., with multiple stems): Euterpe oleracea Mart., Astrocaryum gynacanthum Mart., and Astrocaryum vulgare Mart. Three are singlestemmed species with circular crowns of less than $6 \mathrm{~m}$ in diameter: Syagrus cf. vermicularis Noblick, Socratea exorrhiza (Mart.) H. Wendl., and Acrocomia aculeata (Jacq.) Lodd. ex Mart. The final five species are singlestemmed too but with circular crowns greater than $6 \mathrm{~m}$ in diameter: Oenocarpus bacaba Mart., Mauritia flexuosa L.f., Astrocaryum aculeatum G. Mey., A. maripa (Aubl.) Mart., and A. speciosa Mart. ex Spreng. (i.e., the babassu). Their stems were found to exceed $20 \mathrm{~m}$ in height. These five species are the LCC - Large Circular Crown palms (Table 1) visible on the GeoEye VHSR image (resolution: $0.50 \mathrm{~m}$ ). However, it was impossible to tell them apart. 
Table 1 Morphological characteristics of 12 palm species found on the PA-Benfica a) palm species with large circular crowns - LCC over $6 \mathrm{~m}$, b) palm species with crowns less than $6 \mathrm{~m}$ or non-circular

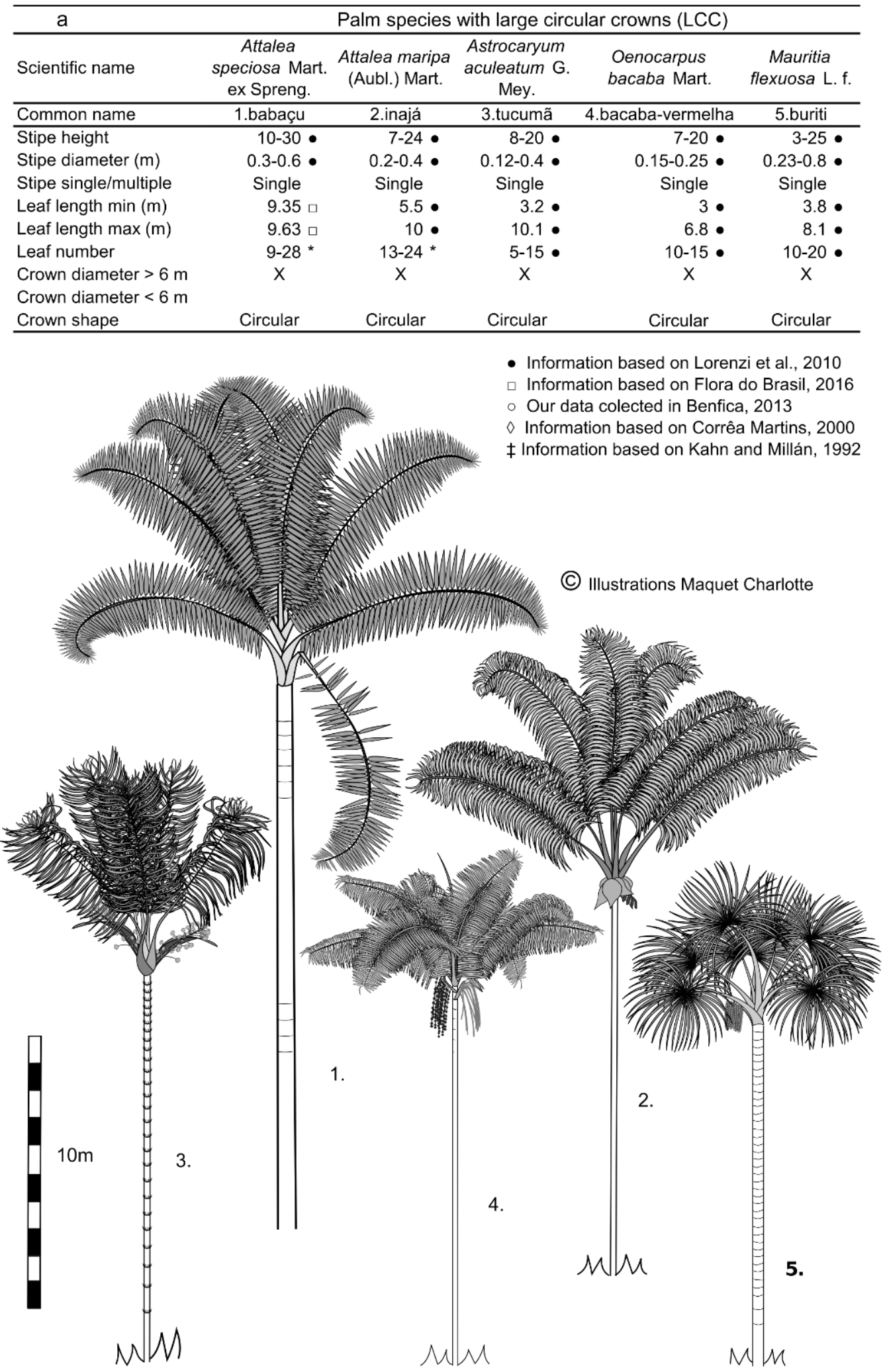




\begin{tabular}{|c|c|c|c|c|c|c|c|}
\hline $\mathrm{b}$ & & & Othe & palm species & & & \\
\hline Scientific name & $\begin{array}{c}\text { Oenocarpus } \\
\text { distichus } \\
\text { Mart. }\end{array}$ & $\begin{array}{c}\text { Syagrus cf. } \\
\text { vermicularis } \\
\text { Noblick }\end{array}$ & $\begin{array}{c}\text { Socratea } \\
\text { exorrhiza } \\
\text { (Mart.) } \\
\text { H.Wendl. }\end{array}$ & $\begin{array}{l}\text { Acrocomia } \\
\text { aculeata } \\
\text { (Jacq.) Lodd. } \\
\text { ex Mart. }\end{array}$ & $\begin{array}{c}\text { Astrocaryum } \\
\text { vulgare } \\
\text { Mart. }\end{array}$ & $\begin{array}{c}\text { Astrocaryum } \\
\text { gynacanthum } \\
\text { Mart. }\end{array}$ & $\begin{array}{c}\text { Euterpe } \\
\text { oleracea } \\
\text { Mart. }\end{array}$ \\
\hline Common name & 6.bacaba & 7.pati & 8.paxiúba & 9.macaúba & $\begin{array}{c}\text { 10.tucum- } \\
\text { bravo }\end{array}$ & 11.mumbaca & $\begin{array}{c}\text { 12.açaí-do- } \\
\text { pará }\end{array}$ \\
\hline Stipe height & $5-10 \bullet$ & $8-14 \bullet$ & $10-20 \bullet$ & $10-15 \bullet$ & $4-10 \bullet$ & $2-6 \bullet$ & $3-20 \bullet$ \\
\hline Stipe diameter $(\mathrm{m})$ & $0.1-\bullet$ & $0.12-\bullet$ & $0.1-\bullet$ & $0.23-0.5 \diamond$ & $0.1-0.2 \bullet$ & $0.03-0.1 \bullet$ & $0.07-\bullet$ \\
\hline Stipe single/multiple & Single & Single & Single & Single & Multiple & Multiple & Multi \\
\hline Leaf length $\min (\mathrm{m})$ & $3.2 \bullet$ & $2.5 \bullet$ & $2.7 \bullet$ & 30 & $4.5 \mp$ & $1.55 \bullet$ & $2 \bullet$ \\
\hline Leaf length $\max (\mathrm{m})$ & $6.9 \bullet$ & $3 \bullet$ & $4.7 \bullet$ & 3.90 & $6 \mp$ & $3.9 \bullet$ & $3 \bullet$ \\
\hline $\begin{array}{l}\text { Leaf number } \\
\text { Crown diameter }>6\end{array}$ & $\begin{array}{c}9-12 \\
x\end{array}$ & $12-15 \bullet$ & $7 \bullet$ & $10-30 \bullet$ & $8-16 \bullet$ & $6-13 \bullet$ & $8-14$ • \\
\hline Crown diameter $<6$ & & $\mathrm{x}$ & $x$ & $x$ & $\mathrm{x}$ & $\mathrm{X}$ & $x$ \\
\hline Crown shape & Rectangular & Circular & Circular & Circular & Circular & Circular & Circular \\
\hline
\end{tabular}

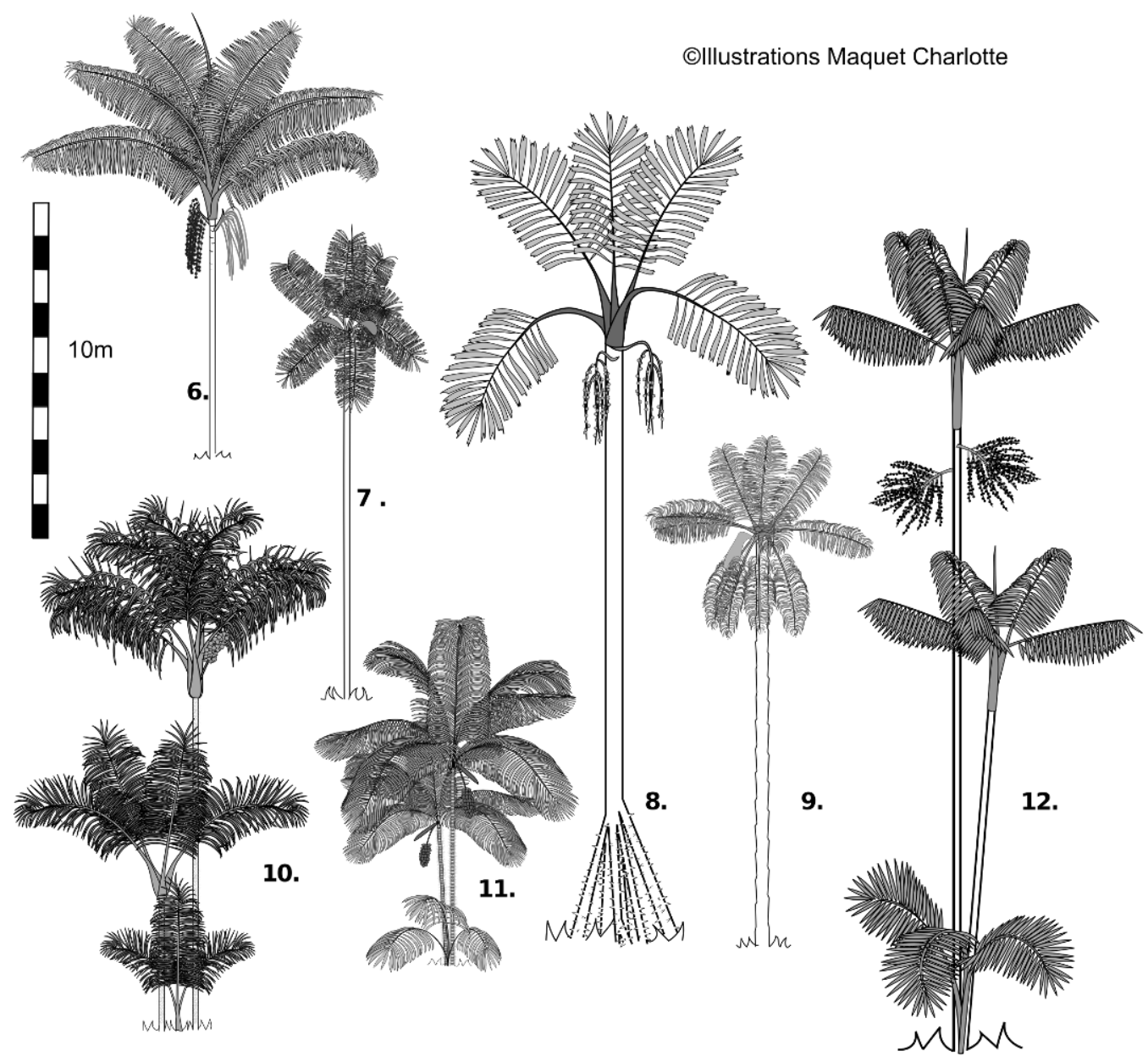

Three of the five LCC palms are common: A. speciosa (babassu), A. maripa (inajá), and A. aculeatum (tucumã). In contrast, $O$. bacaba (bacaba) and $M$. flexuosa (buriti) are less frequently encountered; indeed, $M$. flexuosa is only found in flooded lowlands. The latter two species had not been observed during previous quadrat sampling (2001-2008). 
Field estimates of overall palm density, LCC palm density, and babassu palm density

Based on our field sampling of pastures in PA-Benfica ( $n=62$ pastures; total area covered=487 ha), mean overall palm density is 4.2 individuals/ha, mean LCC palm density is 4.0 individuals/ha, and mean babassu palm density is 3.7 individuals/ha (range $=0$ to 44 ). The babassu accounts for $93.6 \%$ of the LCC palms found in pastures (Table 2).

Table 2 Synthesis of field data from palm trees, LCCs palm trees and babaçu on the PA-Benfica

\begin{tabular}{|c|c|c|c|}
\hline References & $\begin{array}{l}\text { Silva, 2004; } \\
\text { Coelho, 2008; } \\
\text { Barros, } 2007\end{array}$ & $\begin{array}{l}\text { Silva, 2004; } \\
\text { Coelho, 2008; } \\
\text { Barros, 2007 }\end{array}$ & $\begin{array}{c}\text { Santos, 2007; } \\
\text { Santos and Mitja, } 2011\end{array}$ \\
\hline Habitat types & Primary forest & Fallow & Pasture \\
\hline Purpose & \multicolumn{2}{|c|}{ Vegetal biodiversity study } & $\begin{array}{l}\text { Identify the species and } \\
\text { density of trees / palm left } \\
\text { by farmers on pasture }\end{array}$ \\
\hline Choice plots & \multicolumn{2}{|c|}{ Various plots present in lots of farmers } & $\begin{array}{c}\text { Various pastures } \\
\text { belonging to various } \\
\text { farmers and having trees } \\
\text { and palms }\end{array}$ \\
\hline Life stages sampled & \multicolumn{2}{|c|}{$\begin{array}{l}\text { Individuals with more than } 10 \mathrm{~cm} \text { in } \\
\text { diameter, with free air stipe or covered } \\
\text { by leaf sheaths }\end{array}$} & $\begin{array}{l}\text { Individuals with more than } \\
20 \mathrm{~cm} \text { in circumference } \\
(6.37 \mathrm{~cm} \text { diameter) with } \\
\text { free stipe }\end{array}$ \\
\hline Total area sampled (ha) & 0.85 & 1.35 & 487 \\
\hline Plot number & 17 & 27 & 62 \\
\hline Palm density/ha & 96.5 & 92.6 & 4.2 \\
\hline LCC palm density/ha & 21.2 & 33.3 & 4 \\
\hline Babassu density/ha & $21.2^{a}$ & $33.3^{a}$ & $3.7^{*}$ \\
\hline Standard error & 10.9 & 12.5 & 0.9 \\
\hline Minimal density of babassu/ha & 0 & 0 & 0 \\
\hline Maximal density of babassu/ha & 160 & 260 & 44 \\
\hline $\begin{array}{l}\text { Proportion of babassu among } \\
\text { LCC palm (\%) }\end{array}$ & 100 & 100 & 93.6 \\
\hline
\end{tabular}

* The methods of surveying plants in pastures are different from those used in forests and fallows. It was therefore not possible to compare the averages between them

Mean that have the same letter are not different

In primary forest and on fallow land, the babassu was the only LCC palm present. However, we know that A. maripa and A. aculeatum are native to primary forests; however, their densities appear to be low, and they were not observed during our sampling efforts. Consequently, the babassu likely represents close to $100 \%$ of 
LCC palms in primary forest and on fallow land, which is the figure we used in this study. For fallow land and primary forest, mean babassu density was 33.3 individuals/ha (range $=0$ to 260$)$ and 21.2 individuals/ha (range $=0$ to 160), respectively. Densities did not differ between the two habitats (Mann-Whitney-Wilcoxon, with alpha=0.05, $\mathrm{W}=190.5$, p-value 0.2957). Methodological differences in the way palms were counted in pastures versus in primary forest and on fallow land prevent us from meaningfully comparing densities between those habitat types. The density ranges show that the number of individuals varied greatly within each habitat type.

According to field data sample, therefore, what we get is merely a proportion babassu vs LCC (table 2). The high value $(93,6 \%$ for pastures and $100 \%$ for forests \& fallows) are linked both to ecosystem reality and sample effect. From satellite data, we now propose to use these rates to extrapolate the densities of babacu from the densities of palm trees LCC. They can possibly lead to a light overestimation in the case of forests and fallows, what seems to us quite acceptable.

\section{Satellite-image estimates of LCC and babassu palm density}

On the satellite image, $30.5 \%$ of the 2,354 1-ha cells studied (718 cells) contain no LCC palms (Fig. 2). $59.5 \%$ (1401 cells) contain between 1 and 10 LCC palms. The other 10\% (235 cells) contain 11 to 67 palms.

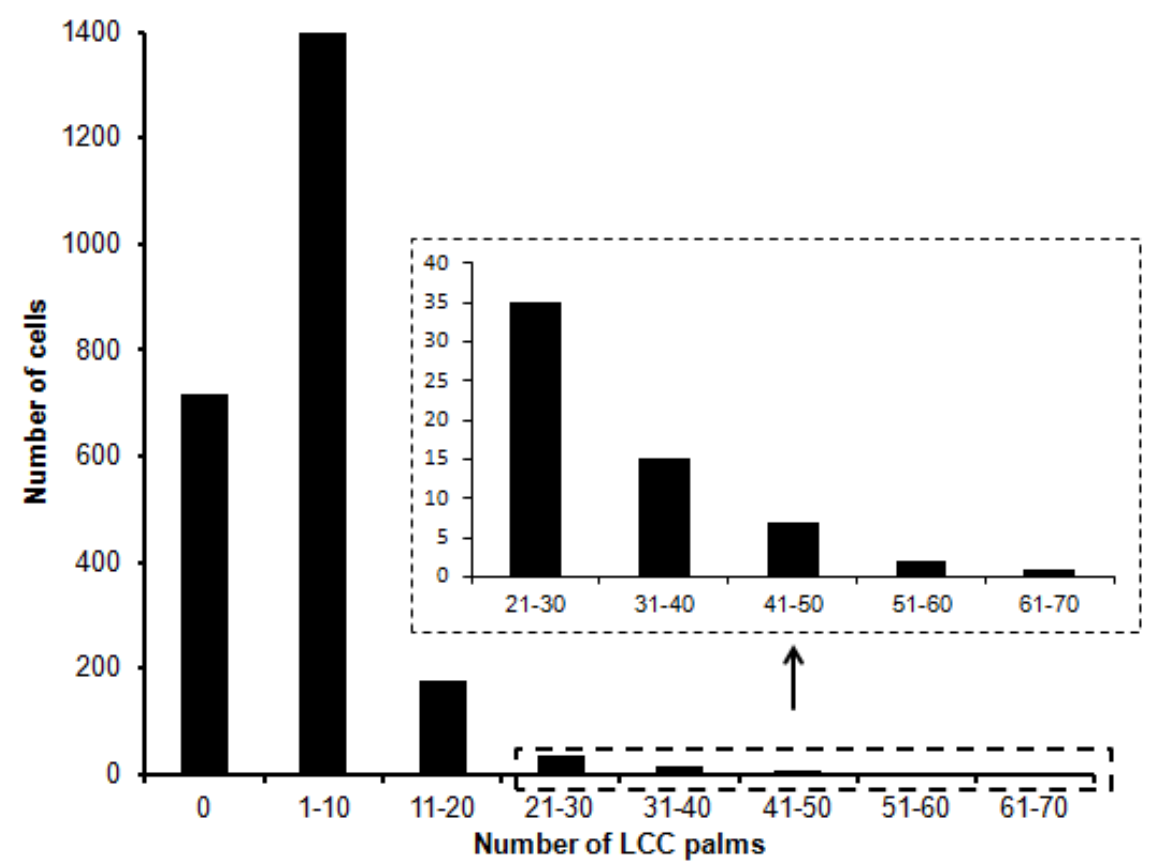

Fig. 2 Density of LCCs palm trees in 2,354 1ha-cells sampled on the PA-Benfica 
Of the 2,354 1-ha cells examined, 39.6\% (933 cells) fall in the mixed-use category and are therefore excluded from further analyses. The remaining $60.4 \%$ (1,421 cells) are classified as primary forest $(4.0 \%)$, fallow land (10.7\%), and pasture (45.7\%). Since nearly $100 \%$ of the LCC palms found in primary forest and on fallow land were babassu palms, babassu density only needs to be extrapolated for pastures. The percentage obtained from the field data—where babassu palms represent $93.6 \%$ of the LCC palms observed—was used. Figure 3 shows the distribution of these 1,421 cells across babassu density categories and habitat types. Using percentages instead of absolute values makes it possible to compare palm occurrence across different habitats. In all three habitats, one-quarter to one-third of the cells contain no babassu palms. The babassu is more frequently absent from fallow land (30.7\%) and especially from pastures (35.4\%) than from primary forest (23.2\%). Nonetheless, across all three habitats, most cells (around 60\%) contained between 1 and 10 individuals. The densities vary: they are never greater than 23 individuals/ha in primary forest but can reach 55 individuals/ha in certain pastures or even 67 individuals/ha on certain tracts of fallow land.

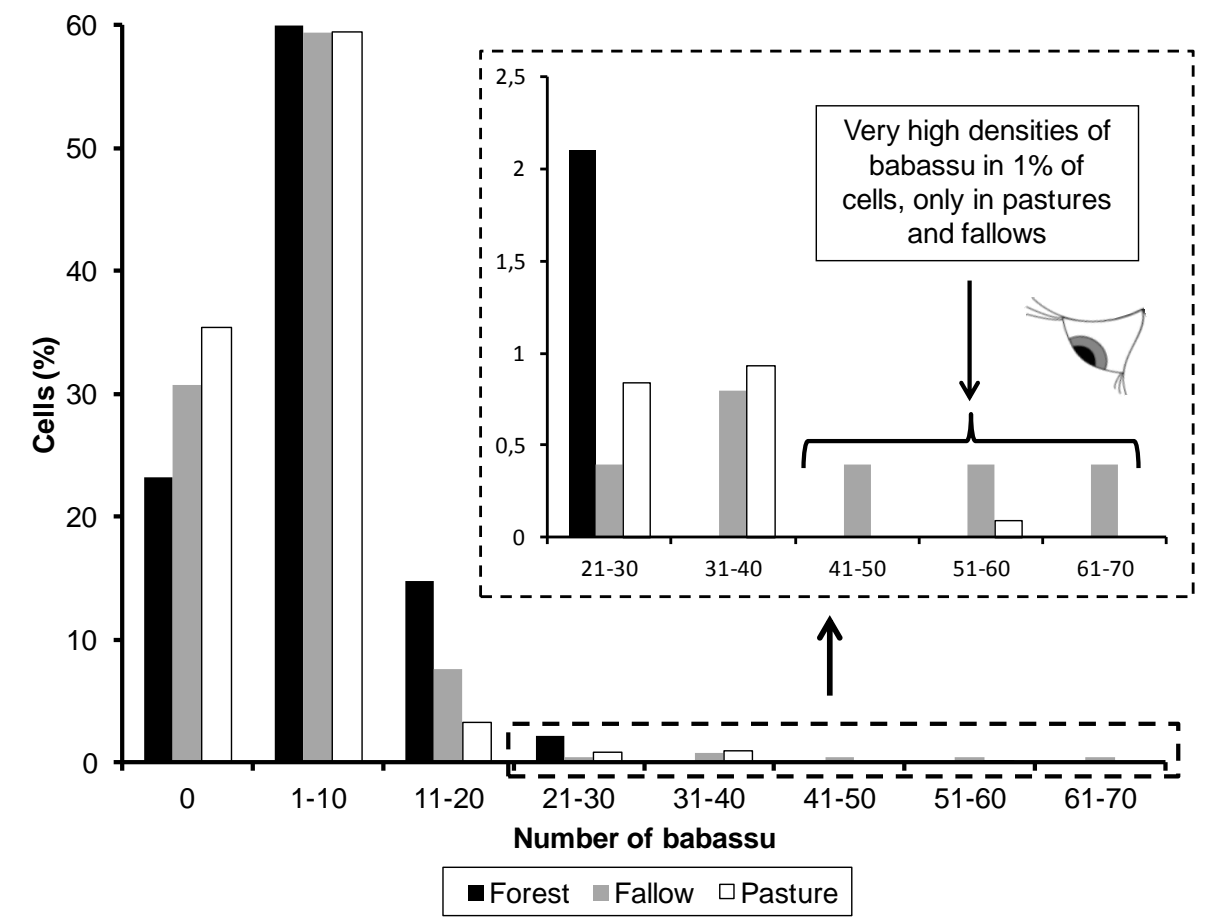

Fig. 3 Density of babassu palms in 1,421 pure 1ha-cells (with one type of land cover), sampled on the PABenfica

The GLM analysis carried out showed that land use is statistically relevant for estimating mean density of babassu ( $\mathrm{p}$-value =2.2e-16). According to the pair-wise comparison - Bonferroni comparison -, mean density 
of babassu observed in pasture is different from the one observed in forest ( $\mathrm{p}$-value $=0.0113$ ), with respectively a mean density of 2.86 and 4.72 individuals/ha. Similarly the mean density of babassu observed on pasture is different from the one observed on fallow land ( $\mathrm{p}$-value $=0.0019)$ with respectively a mean density of 2.86 and 4.31 individuals/ha (Table 3). However, the hypothesis that the mean density of babassu observed in forest is different than the one observed on fallow land was rejected $(\mathrm{p}$-value $=1)$. Although density is highly variable within each of these three habitats, variability was greatest for fallow land.

Table 3 Babassu densities obtained by photo-interpretation of GeoEye image in 3 type of land cover in PABenfica

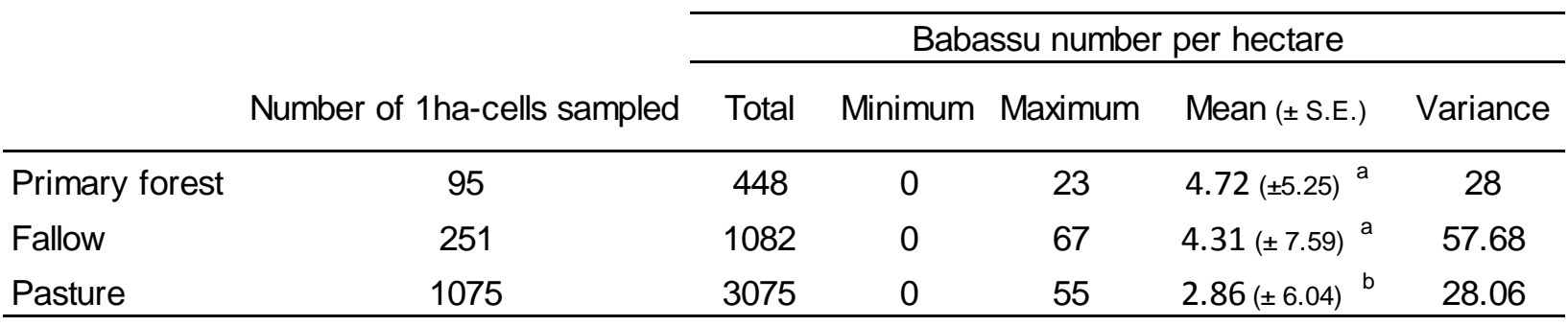

Mean that have the same letter are not different

The mean density of 3.7 individuals/ha measured from the field data does not differ significantly from the mean density of 2.86 individuals/ha estimated using the VHSR satellite images (parametric mean comparison Z-test, $\alpha=0.05, \mathrm{t}=-0.9574, \mathrm{p}$-value 0.3419$)$.

\section{Discussion}

The results obtained on the PA-Benfica indicate that the mean babassu density is higher in the rain forests and fallow land than in pastures. Human activities help explain those results. The resilience of this palm that opposes the human impact plays in favor of the conservation of this important resource.

\section{Comparison between field data and satellite-image data}

Very high spatial resolution (VHSR) satellite images have become available only relatively recently. On them, individual tree and palm species can be detected. While research aimed at identifying species on satellite images is still ongoing (Shafri et al. 2011; Srestasathiern and Rakwatin 2014; Chemura et al. 2015), there is an abundance of field data describing biodiversity at numerous locations. Below, we discuss the possibility of using 
such field data to validate results obtained from VHSR satellite images. We are well equipped to do so in this study since we amassed field data on LCC palm occurrence and density in the context of other research.

As far as pastures are concerned, the sampled areas and the used sampling methods led to satisfactory results. The mean density from the field data does not differ significantly from the mean density estimated using the VHSR satellite images. Therefore, for pastures, field sampling and VHSR-image analysis result in similar findings, thus allowing extrapolation.

In contrast, for fallow land and primary forest, a much smaller area was sampled in the field. Only the most common species — babassu, but no inaja nor tucumã — were observed. This result stems from the fact that the latter two species are rarer and are not seen in the upper forest layer. However, they do occur in the intermediate and lower levels of the forest, in the form of seedlings or young plants that cannot be detected via photo interpretation (Coelho 2008). Furthermore, in primary forest and on fallow land, field sampling also included individuals with buried stems (younger palms); such plants cannot be seen on satellite images. These issues result in very large differences in the mean densities obtained using the two different methodologies. The mean densities of the field data for primary forest and fallow land are much higher than mean densities obtained using satellite images. Therefore, for these two habitat types, the field data cannot be used to validate the satellite-image data. It would be necessary to filter the field data by diameter measurements or the presence/absence of a free air stipe to extract information comparable to that obtained from the satellite images. These data were not recorded in the framework of our study.

\section{Differences in babassu occurrence and density across habitat types}

To understand the current distribution patterns of babassu palms, it is necessary to understand how the landscape has changed over the last 40 years. Tropical rainforest formerly covered the lands now cultivated by PA-Benfica farmers. Progressively, it was cleared to create pastures, some of which were abandoned more or less rapidly. Babassu palms in the primary forest therefore experienced anthropogenic disturbance related to forest clearing and crop planting. Consequently, babassu palm density in a given place at a given time can be explained, in part, by the presence or absence of the species in the initial rainforest vegetation, the nature and intensity of the disturbance forces, and the resistance opposed by the individuals that survived the deforestation process.

Satellite images clearly show that the babassu only occurs in certain parts of the PA-Benfica territory. It is absent from one-quarter to one-third of the cells across all habitat types, but more absent from fallow land 
(30.7\% of cells) and especially from pastures (35.4\% of cells) than from primary forest (23.2\% of cells). The absence of the palm from pastures led a lower mean density for that habitat type possibly linked to the disturbance caused by initial forest clearance or to past agricultural practices. In the other cells, the babassu is present at varying density. Primary forest has a higher percentage of cells containing one to 30 individuals than do fallow land and pasture. The babassu is considered to be invasive (>30 individuals) in only $1 \%$ of cells, which are all fallow land and pasture habitats. Although, overall, babassu density is much lower in pasture than in primary forest, in certain pastures disturbance likely caused the number of babassu palms to explode. In these areas, the babassu outcompetes crop species and the pastures are thus abandoned. The babassu then becomes monodominant in the fallow lands.

We carried out field research in 2003 at the same study site and found there was a greater density of adult babassu in primary forest than in pasture; the species had even higher densities in secondary forest, where it was monodominant (Barot et al. 2005). Although the PA-Benfica lands harbor few tracts of secondary forest, such habitat stands out and generates the impression that babassu density soars when pastures are abandoned. Our results contrast in part with previous findings that the density of adult babassu palms is lower in forests than in disturbed areas (Anderson and May 1985; Peters et al. 1989). It is important to underscore here that field data, which require considerable time and funding to collect nonetheless remain limited in their scope: it is difficult to extrapolate what is found for a small area to a larger region. In our case, at first, the field data was essential to validate the image results. Then, these image results have allowed to visualize dynamics that can only be apprehended at the scale of the landscape, such as the decrease of average densities of babaçu in the PA-Benfica pastures.

\section{Factors influencing the babassu development after forest clearing \\ Babassu resilience in pastures}

The PA-Benfica lands examined in our study are used by small-scale family farmers; labor is manual and input levels are low. Their pastures were generated by the clearing of rainforest; sometimes there was a short period of intermediate farming. Clearcutting and the resulting anthropogenic disturbance lead to dramatic changes to the microclimate and other environmental conditions.

Below, we describe the five main factors that affect the persistence of seedlings and young acaulescent plants (i.e., rosettes) in pastures. They are the following: (i) sun exposure; (ii) fire; (iii) manual and chemical 
weed control; (iv) burial of fruit; and (v) competition with forage grasses. We describe how these factors directly or indirectly influence babassu growth and abundance, sometimes in opposing ways (Table 4).

(i) Sun exposure: Exposure to the sun damages babassu seeds, which means there are fewer seedlings in pastures (Mitja and Ferraz 2001). In contrast, seedlings and young acaulescent plants that become established will grow more rapidly because of the readily available sunlight.

(ii) Fire: The effects of fire are complex. Like exposure to sunlight, exposure to fire tends to irreparably damage the seeds contained within the babassu's indehiscent fruit, especially when the fruit remains at the soil surface (Mitja and Ferraz 2001). In contrast, fruit buried further below are protected. Thus, overall, fire can have a direct negative impact on babassu abundance. Like in some other palms, germination in the babassu is cryptocotylar (Thomlinson 1990; Mitja and Ferraz 2001). The ability of the terminal meristem to extend 25-30 cm down into the soil is known to directly enhance plant resistance (Montúfar et al. 2011; Sanín et al. 2013). Indeed, when a fire passes through, the leaves of seedlings and young acaulescent plants are partially or entirely burned away. However, new leaves are then produced by the buried terminal bud, which allows the babassu to persist in areas that regularly experience fire. Because it takes time to produce the new leaves, fire does slow palm growth. However, because other co-occurring species are also eliminated by fire and demonstrate even slower growth, the babassu indirectly benefits from the absence of competition.

(iii) Manual and chemical weed control: In pastures, manual weed control targets any woody and palm species that are outcompeting forage grasses. Control efforts are frequently conducted annually. In the case of the babassu, the leaves of young incaulescent plants are cut. As with fire, new leaves are quickly produced by the buried terminal meristem. While manual weed control hampers babassu growth, because the plant must invest in new leaves, it does not change abundance. Indeed, it may actually favor the species: because control efforts are uniformly applied to all "weed" species and the babassu can produce new leaves rapidly, the palm can take advantage of the competitor-free space that has been created, at the very least during its initial growth period. Until recently, only fazendeiros used chemical weed control. Herbicides were rarely employed by family farmers. At present, PA-Benfica farmers seem to be using them more and more, although only rarely and solely in cases where young acaulescent plants have reached such extreme densities that they threaten the pasture's viability. In such situations, herbicide is applied to the terminal meristems of acaulescent plants whose tissues are manually damaged beforehand. In some cases, seedlings are also treated. This approach can successfully eliminate almost all of the individuals targeted. 
(iv) Burial of fruits: The fruit of the babassu are heavy and fall at the feet of the parent plants. If they are not dispersed, they may remain at the soil surface. If the soil is wet, they may start to sink down. During the hottest part of the day, cattle often seek shelter in the shade of the palm trees and drive the fruit even further under with their weight. Wild animal species may also consume the fruit's mesocarp and even occasionally bury the fruit (Smith 1974, 2015). The seeds in fruit that are buried well below the soil surface are protected from sun and fire, thus limiting negative effects on abundance.

(v) Competition with forage grasses: At present, the most common forage grass in the Amazon is brachiarão (Brachiaria brizantha Stapf). This grass is relatively aggressive compared to herbaceous weeds (Mitja and Miranda 2010). In the Médio Mearim region in the Brazilian state of Maranhão, it is said that babassu seedlings and young plants can be eliminated by the introduction of forage grass, although the potential mechanisms in operation remain unknown (da Silva 2008). However, on PA-Benfica lands, young babassu palms appear to be unaffected by brachiarão. After fire or weed control efforts, they rapidly resprout and outcompete the brachiarão, which covers the entire soil surface but is maintained at a maximum height of $80 \mathrm{~cm}$ (Mitja et al. 2000). Although babassu seedlings may be completely hidden by the forage plant, their abundance is only slightly affected. They are more often eliminated because they are trampled by cattle making their way along paths through the pastures. In pastures where Brachiaria brizantha is thriving, the growth of palm seedlings and young plants may be reduced due to competition with the forage plant; however, the strength of this effect remains to be quantified.

Three main factors affect the persistence of young caulescent and adult plants in pastures. They are the following: (i) clearfelling; (ii) sun exposure; and (iii) fire. Below, we describe how these factors directly or indirectly influence babassu growth and abundance (Table 4).

(i) Clearfelling: When rainforests are cleared, farmers may fell certain adult plants. (Table 4). Often, the tallest individuals are targeted because they present a risk to cattle and humans during windy conditions (Carvalho, com. pers.). It is likely that such felling practices have led to the babassu's relatively greater absence from fallow land and pasture. This same initial cut, associated with some mortality (decline of individuals in poor condition following the opening of the medium) which also explains a lower proportion of cells having between 1 and 30 individuals babassu in pastures and fallow lands compared to forests. In general, young plants with stems less than $3 \mathrm{~m}$ high are not felled for two reasons. First, farmers say that palms under $3 \mathrm{~m}$ do not 
present a danger to cattle and humans, in contrast to taller plants. Second, they contend that the stems of such palms are difficult to cut through and tools may be damaged in the attempt (Carvalho, com.pers.).

Table 4 Various factors impact on the babassu palm, in pasture

\begin{tabular}{|c|c|c|c|c|}
\hline & \multicolumn{2}{|c|}{ Fruits } & \multicolumn{2}{|c|}{ Life cycle } \\
\hline & $\begin{array}{l}\text { Above the } \\
\text { ground }\end{array}$ & Buried & $\begin{array}{l}\text { Seedlings } \\
\text { and young } \\
\text { individuals } \\
\text { stemless }\end{array}$ & $\begin{array}{l}\text { Young with } \\
\text { stipe and } \\
\text { adults }\end{array}$ \\
\hline Sun & \multirow{2}{*}{$\begin{array}{c}\text { Seed } \\
\text { deterioration, } \\
\text { eliminates } \\
\text { potential } \\
\text { individuals }\end{array}$} & \multirow{2}{*}{$\begin{array}{c}\text { Very low } \\
\text { deterioration } \\
\text { of seeds, little } \\
\text { impact on the } \\
\text { individuals } \\
\text { number }\end{array}$} & \multicolumn{2}{|c|}{ Promotes growth } \\
\hline Fire & & & \multirow{2}{*}{$\begin{array}{l}\text { Slows the } \\
\text { growth and } \\
\text { indirectly } \\
\text { promotes } \\
\text { growth, no } \\
\text { impact on the } \\
\text { individuals } \\
\text { number }\end{array}$} & $\begin{array}{c}\text { Slow growth, } \\
\text { can eliminate } \\
\text { some } \\
\text { individuals }\end{array}$ \\
\hline Hand weeding plot & & & & \\
\hline $\begin{array}{l}\text { Specific chemical weeding } \\
\text { babaçu }\end{array}$ & & & $\begin{array}{l}\text { Eliminates } \\
\text { individuals }\end{array}$ & \\
\hline Competition forage grass & & & Slows growth & \\
\hline Clearcutting & & & & $\begin{array}{l}\text { Eliminates } \\
\text { individuals }\end{array}$ \\
\hline
\end{tabular}

(ii) Sun exposure: As in the case of seedlings and young acaulescent plants, exposure to the sun has positive effects on the growth of young caulescent and adult plants. Light availability in pasture's open environment means the babassu can reach reproductive maturity at only about 10 years of age; as mentioned above, the process takes about 108 years in primary forest (Anderson et al. 1991). Infructescence density is also greatest in open environments. (Silva 2008).

(iii) Fire: The impact of a given fire on young caulescent and adult plants is a function of a pasture's accumulated biomass. If levels are low, the fire will burn less intensely and for a shorter time period. It is therefore less likely to burn away the leaves of the young caulescent and adult plants, which are located at a certain height above the soil surface. If levels are high, the fire will burn with greater intensity and for a longer time period, which means that entire plants may be incinerated. However, even in such situations, most 
individual plants will survive and rapidly begin to produce new leaves, thanks to their sheathed terminal meristems. At most, intense, longer-burning fires will slow down babassu growth and destroy the current year's fruit. Future fruit production will not be affected however.

Mean babassu density is lower in pasture (2.86 individuals/ha) than in primary forest (4.72 individuals/ha). This result underscores that, even if babassu density is very high in certain pastures, the species' ability to resist disturbance forces cannot entirely counteract their negative effects on growth and abundance across the PA-Benfica lands as a whole.

\section{Babassu resilience on fallow lands}

In recently abandoned pastures (i.e., « young fallow lands »), the babassu experiences conditions similar to those in actively managed pastures. As time passes, in oldest fallow lands, conditions will become more and more similar to those found in primary forest. When pastures are abandoned, manual and chemical weed control comes to an end, as does controlled burning, even if the occasional fire may accidently break out. In these former pastures, become fallow land, secondary successional vegetation rapidly takes over. Palms and woody species quickly spread and outcompete forage grasses, which progressively disappear. Depending on their age and state at the moment they are allowed to turn fallow land, abandoned pastures can display very different characteristics (Mitja et al. 2008). They may be covered by herbaceous plants or diverse woody species. They can alternatively harbor monodominant stands of babassu (especially in the case of major babassu invasions). Such stands visually dominate the landscape, even though they represent a very small percentage of the PA-Benfica lands.

On fallow land, where there is no longer any anthropogenic disturbance, the babassu spreads rapidly. Mean density is high as compared to that observed in actively managed pastures. It is comparable, however, to the mean density in primary rainforest. In certain areas, palm density on fallow land may even greatly surpass the maximum values observed in primary forest.

\section{Conclusion}

This study was an initial effort to understand the relationships among measures of palm tree density (individuals/ha) in multiple habitat. Thus, when primary forest is cleared to create croplands and pastures, the babassu palm can quickly grow in these areas and colonize fallow land by creating monodominant secondary forests. But, in other cases, the same process results in the disappearance of the babassu, most commonly in 
zones where the palm natural density, i.e. before clearing, was low. Besides the initial deforestation, if they wish to remove the babassu from their agroecosystems, the farmers may practice targeted clearcutting and contribute to a significant decrease of palm density, always in the same type of areas. In other words, the babassu palm density value in pastures habitat is dependent on increase determinants (light due to clearing, fire resistance...) or decrease determinants (clearcutting, low natural density...).

The findings presented here challenge the wide-spread idea of higher babassu density in clearing zone than natural density in rain forest by analyzing very high spatial resolution images:

- these satellite data revealed that, on PA-Benfica lands in Brazil, the mean babassu density decreased after clearcutting and burning of primary forest. Although resilient, in actively managed pastures, the babassu palm is unable to completely compensate for the negative effects of anthropogenic disturbance. In contrast, when pastures are abandoned - and as a result, agricultural practices such as weed control and burning no longer occur — babassu density increase significantly;

- the few fallow lands on which babassu palms are densely packed, at eye-level, contribute to the general impression that the babassu is invading agricultural lands but our satellite images analysis revealed that, considering all the fallow lands across the study site, the mean babassu density is actually quite moderate and comparable to the one in primary forest;

- furthermore, on PA-Benfica lands, the surface area dedicated to pasture is increasing at the expense of primary forest or fallow land and more chemical herbicides are being used; both these trends are driving babassu densities down;

- in contrast, the harvesting of babassu fruit, which remains limited at present in our site of interest, has very little influence on babassu abundance.

One promising way to overcome the challenges identified is clearly to understand of how the different endogenous or exogenous factors impact the babassu palm life cycle will help in to design future effective management plans for this resources species. Moreover, taking into account species specificities, the methods we developed to study the spatial distribution of the babassu palm can be applied to others palms and trees species in similar problematic issues.

\section{References}

Anderson A B, May P M (1985) A palmeira de muitas vidas. Ciencia Hoje 4:58-64 
Anderson A B, May P H, Balick M (1991) The subsidy from Nature: Palm forests, peasantry, and development on an Amazon frontier. Columbia University Press, New York

Anderson A (1983) The biology of Orbignya matiana (Palmae): A tropical dry forest dominant in Brazil.

Dissertation, University of Florida

Aouragh M, Lacaze B, Hotyat M, Ragala R, Aboudi A E (2013) Cartographie et suivi de la densité des arbres de l'arganeraie (sud-ouest du Maroc) à partir d'images de télédétection à haure résolution spatiale. Revue Française de Photogrammétrie et de Télédétection 203:3-9

Araújo R F, Lopes M A (2012) Diversity of use and local knowledge of palms (Arecaceae) in eastern Amazonia. Biodivers Conserv 21:487-501

Ardila J P, Bijker W, Tolpekin A, Stein A (2012a) Context-sensitive extraction of tree crown objects in urban areas using VHR satellite images. Int J Appl Earth Obs 15:57-69

Ardila J P, Bijker W, Tolpekin V, Stein A (2012b) Multitemporal change detection of urban trees using localized region-based active contours in VHR images. Remote Sens Environ 124:413-426

Barot S, Mitja D, Miranda I, Meija G, Grimaldi M (2005) Reproductive plasticity in an Amazonian palm. Evol Ecol Res 7:1051-1065

Barros, M. N. R., 2007. Mudanças florísticas e estruturais durante o processo de degradação das florestas ripárias no sudeste do Estado de Pará, Brasil. Master's thesis, Universidade Federal Rural da Amazônia

Chemura A, Van Duren I, Van Leeuwen L M (2015) Determination of the age of oil palm from crown projection area detected from WorldView-2 multispectral remote sensing data: The case of Ejisu-Juaben district, Ghana. ISPRS Journal of Photogrammetry and Remote Sensing, High-Resolution Earth Imaging for Geospatial Information 100:118-127

Coelho, R. de F. R., 2008. Padrões e processos agroecológicos no assentamento Benfica, Município de Itupiranga, Pará. Dissertation, Universidade Federal Rural da Amazônia

Corrêa Martins R (2000) A família Arecaceae no Distrito Federal (Brasil). Master's thesis, Universidade de Brasília

Culvenor D (2002) TIDA: an algorithm for the delineation of tree crowns in high spatial resolution remotely sensed imagery. Computers \& Geoscience 28:33-44

Da Silva A (2008) Efeitos alelopáticos causados pelo capim brachiarão (Brachiaria brizantha) no desenvolvimento inicial da palmeira de babaçu (Orbignya Spp.). Revista Verde 3:1-7

Faminow M (1997) Spatial economics of local demand for cattle products in Amazon development. Agr Ecosyst Environ 62:1-11 
Fearnside P (2001) Land-tenure issues as factors in environmental destruction in Brasilian Amazonia : the case of southern Pará. World Dev29:1361-1372

Flora do Brasil 2020 em construção (2016) Arecaceae. Jardim Botânico do Rio de Janeiro. http://www.floradobrasil.jbrj.gov.br/reflora/floradobrasil/FB15686. Accessed 14 November 2016

Fujisaka S, Escobar E, Veneklaas E (2000) Weedy fields and forests : interactions between land use and the composition of plants communities in the Peruvian Amazon. Agr Ecosyst and Environ 78:175-186

Fujisaka S, Escobar G, Veneklaas E (1998) Plant community diversity relative to human land uses in an Amazon forest colony. Biodivers conserv7:41-57

Henderson A (1995) The palms of the Amazon. Oxford University Press Oxford

Henderson A, Galeano G, Bernal R (1995) Field guide to the Palms of the Americas. Princeton University Press Princeton

ISSS-Working-Group (1998) World reference base for soil resources: introduction. (Deckers J A, Nachtergaele F O, Spaargaren O C (eds)), ISSS/ISRIC/FAO, Ed ACCO, Leuven

Jing L, Hu B, Noland T, Li J (2012) An individual tree crown delineation method based on multi-scale segmentation of imagery. ISPR Journal of photogrametry and remote sensing 70:88-98

Kahn F, De Granville J-J (1992) Palms in forest ecosystems of Amazonia. Springer-Verlag, Paris

Kahn F, Millán B (1992). Astrocaryum (Palmae) in Amazonia. A preliminary treatment. Bulletin del'Inst Français des Etudes Andines 21:459-531.

Ke Y, Quackenbush L (2011) A review of methods for automatic individual tree-crown detection and delineation from passive remote sensing. Int J Remote Sens 32:4725-4747

Koch B, Svoboda J, Adler P, Dees M (2002) Automatic tree species detection based on digitised CIR aerial photos. Allg Forst Jagdztg 173:131-140

Leadley P, Pereira H A, Fernandez-Manjares J, Proenca V, Scharlemann J, Walpole M (2010) Biodiversity scenarios: projections of the 21 st centyry change in biodiversity and associated ecosystem services. Secretariat of the Convention on Biological Diversity, Montreal

Lorenzi H, Noblick L, Kahn F, Ferreira E (2010) Flora Brasileira Lorenzi, Arecaceae (Palmeiras). Instituto Plantarum, Nova Odessa

Macedo D (2015) Palmier babaçu et sociétés en Amazonie: Enquêtes et cartographie par télédétection (Etat du Pará, Brésil). Université de Montpellier 2 et 3 
Mathieu J, Rossi J-P, Grimaldi M, Mora P, Lavelle P, Rouland C (2004) A multi-scale study of soil macrofauna biodiversity in Amazonian pastures. Biol Fertil Soils 40:300-305

May P, Anderson A, Balick M, Frazão J (1985) Subsistencebenefits from the babassu palm (Orbignya martiana). Econ Bot 39:113-129

Mitja D, Ferraz I (2001) Establishment of babassu in pastures in Pará, Brazil. Palms 45:138-147

Mitja D, Miranda I (2010) Weed community dynamics in two pastures grown after clearing Brasilian Amazonian rainforest. Weed res 50:163-173

Mitja D, Leal Filho N, Topall O (2000) Impact of fodder crops: Panicum maximum and Brachiaria brizantha on weeds in certain pastures in the parish of Jacundá (Marabá region, Pará, Brazil). In: III International Weed Science Congress, Foz do Iguaçu

Mitja D, Miranda I, Velasquez E, Lavelle P (2008) Plant species richness and floristic composition change along a rice-pasture sequence in subsistence farms of Brasilian Amazon, influence on the fallows biodiversity (Benfica, State of Pará). Agr Ecosyst Environ 124:72-84

Montúfar R, Anthelme F, Pintaud J-C, Balslev H (2011) Disturbance and resilience in tropical american palm populations and communities. Bot Rev 77:426-461

Mougel B, Lelong C (2008) Classification and information extraction in very high resolution satellite images for tree crops monitoring. In: 28th EARSel Symposium Remote Sensing for a Changing Europe, Istambul

Mougel B, Lelong C, Nicolas J-M (2007) Comparison of three segmentation methods for groves recognition in very high resolution satellite images. In: Proceedings of the "PSIP 2007 Conference - Physics in signal and image processing", Mulhouse

Peters C, Balick M, Kahn F, Anderson A (1989) Oligarchic forests of economic plants in Amazonia: Utilization and conservation of an important tropical resource. Conserv Biol 3:341-349

Pintaud J-C (2008) An overview of the taxonomy of Attalea (Arecaceae). Rev Peru Biol 15:55-63

RADAMBRASIL (1974) RADAM, Folha SB.22 Araguaia e parte da folha SC.22 Tocantins. Departamento Nacional de Produção Mineral, Rio de Janeiro

R Development Core Team (2011) R: A language and environment for statistical computing. R Foundation for Statistical Computing, Vienna, Austria. ISBN 3-900051-07-0, URL http://www.R-project.org. Accessed 12 February 2014

Reynal V, Muchagata M, Topall O, Hébette J (1995) Agricultures familiales et développement en front pionnier amazonien. Gret-UAG-UFPa, Point à Pitre 
Rufino M, Costa J, Da Silva V, Andrade L (2008) Conhecimento e uso do ouricuri (Syagrus coronata) e do babaçu (Orbignya phalerata) em Buique, PE, Brasil. Acta Botanica Brasilica 22:1141-1149

Sala O, Chapin I, Armesto J, Berlow E, Bloomfield J D-S, Huenneke L, et al.(2000). Global Biodiversity scenarios for the year 2100. Science 287:1770-1774

Sanín M, Anthelme F, Pintaud J-C, Galeano G, Bernal R (2013) Juvenile resilience and adult longevity explain residual populations of the Andean wax palm Ceroxylon quindiuense after deforestation. Plos One 8:1-16

Santos, M. dos, A. 2007. Estrato arbóreo nas pastagens de agricultores familiares da comunidade de Benfica, Itupiranga-PA. Trabalho de conclusão de curso de Bacharelado em Agronomia T.C.C.,Universidade Federal do Pará

Santos A, Mitja D (2011) Pastagens arborizadas no projeto de assentamento Benfica, Município de Itupiranga, Pará, Brasil. Revista Arvore 35:919-930

Shafri H, Hamdan N, Saripan M (2011) Semi-automatic detection and counting of oil palm trees from high spatial resolution airborne imagery. Int J Remote Sens 32:2095-2115

Shiraishi-Neto J (1999) As quebradeiras de coco no meio norte. NAEA. Belém

Silva, M. A. L. da, 2004. Análise estrutural de florestas secundárias e remanescentes florestais no sudeste do Pará, Brasil. Master's thesis, Universidade Federal Rural da Amazônia

Silva M (2008) Distribuição do babaçu e sua relação com os fatores geoambientais na bacia do Rio Cocal, Estado do Tocantins. Master's thesis, Universidade de Brasília

Smith N (1974) Agouti and babassu. Oryx 12:581-582

Smith N (2015) Palms and people in the Amazon. Geobotany Studies, Basics, methods and case studies. Springer, New York

Srestasathiern P, Rakwatin P (2014) Oil Palm Tree Detection with High Resolution Multi-Spectral Satellite Imagery. Remote Sensing, 6:9749-9774

Thales M (1999) Imagem fração sombra na caracterização e mapeamento de babaçu (Attalea speciosa Mart ex Spreng.) em áreas de floresta. Master's thesis, INPE

Tomlinson P (1990) The structural biology of palms. Clarendon Press, Oxford

Wood S, Ehui S, Alder J, Benin S, Cassman K, Cooper H, et al. (2005) Food. In: Hassan R., Ashi N, Ecosystems and human Well-being : Current state and trends. Island Press Washington, pp 209-242 